\title{
The effect of Malaysian stingless bee, Trigona spp. honey in promoting proliferation of the undifferentiated stem cell
}

\author{
Mohd Amin Marwan Mohamad ${ }^{a}$, Muhammad Alif Mazlan', Muhammad Ibrahim ${ }^{\mathrm{b}, \mathrm{d}}$, Afzan Mat \\ Yusof ${ }^{\mathrm{c}, \mathrm{d}}$, Shamsul Azlin Ahmad Shamsuddin ${ }^{\mathrm{e}}$, Nik Fakhuruddin Nik Hassan ${ }^{\mathrm{f}}$, Hussin Muhammad ${ }^{\mathrm{g}}$, \\ Muhammad Lokman Md. Isa ${ }^{\mathrm{c}, \mathrm{d}^{*}}$ \\ ${ }^{a}$ Department of Biomedical Sciences, Kuliyyah of Allied Health Sciences, International Islamic University Malaysia, 25200 Kuantan, Pahang
Malaysia \\ ${ }^{b}$ Department of Nutrition Science, Kuliyyah of Allied Health Sciences, International Islamic University Malaysia, 25200 Kuantan, Pabang \\ Malaysia \\ ${ }^{`}$ Department of Basic Medical Sciences, Kuliyyah of Nursing, International Islamic University Malaysia, 25200 Kuantan, Pahang Malaysia \\ 'IIUM Human Molecular and Cellular Biology Research Cluster (iMoleC), International Islamic University Malaysia, 25200 Kuantan, Pahang \\ Malaysia \\ 'Institute of Biological Sciences, Faculty of Science, Universiti Malaya, Kuala Lumpur, Malaysia \\ FForensic Science Programme, School of Health Sciences, Universiti Sains Malaysia \\ ${ }^{g}$ Ministry of Health Malaysia
}

Received 8th August 2018 / Accepted 6th December 2018

\begin{abstract}
Stem cells provide various potential applications in regenerative medicine through its ability of self-renewal and differentiation. Among the various stem cells, dental pulp stem cells (DPSCs) have shown encouraging results in their ability to regenerate. Honey has been used in traditional culture as a natural medicine in supporting wound healing. Yet, very few studies on honey were conducted for its potential as a proliferative agent for stem cells. The aim of this study is to evaluate the stability of two Trigona spp. honeys (1 and 2 ) added in culture media and its proliferative effect on DPSCs. Both honeys were diluted with standard culture medium through dilution process to prepare the concentrations of $0.01 \%, 0.04 \%$, $0.10 \%$ and $0.25 \%$. DPSCs were treated with the diluted honeys for 24 hours. The proliferative activity was determined through the images taken using an inverted microscope for every six hours. In addition, the MTT assay was conducted to determine the cell viability of DPSCs when treated with both honey 1 and 2 at various concentrations. The results showed a stable culture media added with honey for three days and a dose-dependent proliferative effect of both Trigona spp. honey samples on DPSCs. Optimum proliferative effects were observed at 24 hours for both Trigona spp. honey 1 and 2 on DPSCs. The optimum concentration of Trigona spp. honey 1 was from $0.04 \%$ to $0.10 \%$ and Trigona spp. honey 2 was below $0.01 \%$. It is concluded that Trigona spp. honey has a promising proliferative effect on DPSCs.
\end{abstract}

Keywords: Trigona spp. honey, mesenchymal stem cells, dental pulp, DPSCs, kelulut

\section{INTRODUCTION}

In recent years, many studies have focused on the possible application of stem cells to mend and regenerate body structures. By definition, stem cell is a cell that has the ability to divide (selfreplicate) for indefinite periods throughout the life of the organism (Chandross \& Mezey, 2001). Stem cells are immature, unspecialised cells that have the potential to develop into many different cell lineages. For example, they can develop into mature cells that have characteristic shapes and

\footnotetext{
* Author for correspondence: Muhammad Lokman Md. Isa, International Islamic University Malaysia, Jalan Sultan Ahmad Shah, Bandar Indera Mahkota, 25200 Kuantan, Pahang, Malaysia. Email - lokman@iium.edu.my
} 
specialised function, such as heart cells, skin cells, or nerve cells. Generally, stem cell research in regenerative medicine focuses on restoring the vitality and function of diseased and traumatised tissue (Noce et al., 2014).

Mesenchymal stems cell (MSC) was obtained from the dental pulp of teeth. Dental pulp is a connective tissue that contains MSCs known as dental pulp stem cells (DPSCs) that is relatively easy to be obtained from the exfoliated primary teeth or extracted permanent teeth (Piva, Silva \& Jacques, 2014) and is able to differentiate into different kinds of cells and tissues. As compared to bone marrow MSCs, DPSCs has higher proliferation rate, availability, and greater cell number (Noce et al., 2014).

In the context of regenerative therapies, DPSCs hold great promise for cell therapy approaches in dentistry with studies already showing encouraging results in their ability to regenerate bone and periodontal tissues. Specifically, the identification of DPSCs promises a great potential in the regeneration of lost dental pulp and tooth tissues because of their ability to differentiate into dentin and pulp-like tissue (Eubanks et al., 2014). Previous studies from Obeid et al. (2013) have shown that DPSCs are putative candidate cells for tooth and bone-tissue engineering. The identification of the MSCs capability in regenerating organised tooth-like structures has increased the interest in the potential use of postnatal stem cell-based therapies for dental tissue regeneration after trauma or disease.

Honey is a naturally available food with a long history of traditional use as an active medicinal compound in a large number of cultures. It contains a variety of phytochemicals with high flavonoid and phenolic content that become the main sources of high antioxidant activity of honey (Yao et al., 2003). Various findings have proven that this natural product does not only exhibit antioxidant properties, but also immunoregulatory, chemopreventive, antiatherogenic, wound healing, and antimicrobial properties (Molan, 2006; Tsiapara et al., 2009; Khalil et al., 2010; Sherlock et al., 2010).

In this respect, honey is well known for its healing potential. Understanding the healing potential in honey requires an understanding of the detail of its physico-chemical characterisation and also an analysis of biological impacts at different concentrations/dilutions at different levels (e.g. cellular and molecular) (Chaudhary et al., 2015). Research on the benefits of honey for health industry has been extensively conducted in many countries all over the world. However, there are few findings on the benefits of various honeys that exist in Malaysia, particularly Trigona spp. honey. In a comparison between the Tualang and the Trigona spp. honey, the latter has not been widely studied with only several findings on the effect of Trigona spp. propolis are reported. Thus, it is important to thoroughly study the benefits and potential contributions of the Malaysian stingless bee honey to the human health, especially as a proliferative agent.

Honey produced by stingless bee (Trigona spp.), which is also known as 'kelulut' in Malaysia, has been identified to have medicinal values. Trigona spp. honey is widely used by the aborigines and is considered to induce better performance than honeybee honey (Shahjahan et al., 2007). The Malaysian Agricultural Research and Development Institute (MARDI) in Malaysia conducted research on this species and found that Trigona spp. consists of over 30 species in Malaysia. Among the species of Trigona spp. are Trigona itama, Trigona apicalis, Trigona laeviceps, and Trigona thorasica (Aquaponic Cultures Malaysia [ACM], 2012).

Trigona species are distributed throughout the tropical and subtropical parts of the Aftrotropical, Australasian, Indo-Malayan, and Neotropical regions (Klasikorn et al., 2005). Among the countries that have been identified to own Trigona spp. are Indonesia (37 species), Thailand (20 species), Vietnam (9 species), India (3 species), Taiwan (1 species) and Malaysia (more than 30 species) (ACM, 2012).

Healing with diluted honey rather than its raw form is also proposed considering the fact that a low concentration of hydrogen peroxide in a healing agent has bactericidal effect but is not toxic on mammalian cells (Molan, 2006). Therefore, knowledge on the optimum dilution of honey is imperative in order to determine its maximum healing efficiency. Impacts of specific honey dilutions on epithelial cell population in vitro also need to be investigated.

Herein, this study aimed to investigate the potential role of Trigona spp. honey in proliferative 
effect on dental pulp stem cells (DPSCs). Hence, this study is designed to evaluate the differential dosage effect of Trigona spp. honey. It is hypothesised that honey from this species is able to increase the proliferative activity of DPSCs in a dose- and time-dependent manners.

\section{MATERIALS AND METHODS}

\begin{abstract}
Honey procurement. Trigona itama species honey from two different places were procured from Assoc. Prof. Dr. Muhammad bin Ibrahim, from Department of Nutrition Science, Kulliyyah of Allied Health Science, International Islamic University Malaysia (IIUM). It was available in the market and the places were not to be revealed in this study in order to avoid any conflict of interest.
\end{abstract}

\section{Dental pulp stem cells (DPSCs) procurement.} Human DPSCs (Passage 10, P10) were obtained from Dr. Shamsul Azlin (which was derived from his lab), The Department of Biology, University Malaya. The validations of cells were done by identifying the protein specific markers of CD105 and CD90 with fibroblast-like shape of the cells (Helena, Alencar, \& Kitten, 2011; Nikolić et al., 2011). The cells were cultured and maintained in Molecular and Cellular Biology Lab, Integrated Centre for Research Animal Care and Use (ICRACU), IIUM.

Serial dilution of honey. The sample was kept in a tightly packed and sterilised container to avoid contamination until use and was certified by the Ministry of Health Malaysia $(\mathrm{MOH})$ for marketing purposes. The absolute honey $(100 \%)$ with the initial $\mathrm{pH} 3.3$ and moisture content of $12 \%$ was then diluted at the concentrations of $0.01 \%(\mathrm{v} / \mathrm{v})$, $0.04 \%(\mathrm{v} / \mathrm{v}), 0.10 \%(\mathrm{v} / \mathrm{v})$, and $0.25 \%(\mathrm{v} / \mathrm{v})$ with culture medium. The honey mixtures were prepared 24 hours before being tested to cell lines and stored at $4^{\circ} \mathrm{C}$ until use.

Media stability test. Each media was prepared with different concentrations of Trigona spp. honey 1 and 2 . About $5 \mathrm{ml}$ of each concentration were delivered into T25/25 $\mathrm{cm}^{2}$ cell culture flasks. Then, the media added with honey was kept in 5\% $\mathrm{CO}_{2}$ incubator at $37^{\circ} \mathrm{C}$ for three days. Images were taken before and after three days in the incubator using EVOS XL CORE (Thermo Fisher Scientific, USA).

Cell culture. DPSC lines were propagated in Dulbecco's modified Eagle's medium (DMEM) in three different cell culture flasks, all supplemented with 10\% fetal bovine serum (FBS) and 5\% penicillin/ streptomycin, and maintained at $37^{\circ} \mathrm{C}$ in $5 \% \mathrm{CO}_{2}$ incubator.

Proliferation test. The proliferation test was performed based on the work of Fauzi et al. (2011) using haemocytometer with modification. In order to perform the proliferation assay for DPSC lines, at least 5,000 or $5 \times 10^{3}$ cells per well are recommended. The cells were seeded in 12-well plate at three different cells density; $5 \times 10^{3}$ cells, $10 \times 10^{3}$ cells, and $15 \times 10^{3}$ cells well. The cells were incubated overnight at $37^{\circ} \mathrm{C}$ with $5 \% \mathrm{CO}_{2}$ and treated for 24 hours at four different concentrations of both Trigona spp. honey samples 1 and $2(0.01 \%, 0.04 \%, 0.10 \%$ and $0.25 \%$ respectively). Images were taken using an inverted microscope for every 6 hours interval until 24 hours of treatment at 10X magnification.

Evaluation of cell viability in media added with honey and control. In this study, we conducted the cell viability by using (3-(4,5dimethylthiazol-2-yl) -2,5-diphenyltetrazolium bromide [MTT]) colorimetric assay. DPSC cell lines were seeded at a density of 5000, 10000, and 15000 cells/well in a 96-well plate. The bestseeded number of cells was analysed in this paper. The three densities were chosen based on the optimum densities obtained from the proliferation test. After an incubation period of 24 hours, the cells were washed with phosphate buffered saline (PBS). The different concentrations $(0.01 \%(\mathrm{v} / \mathrm{v}), 0.04 \%(\mathrm{v} / \mathrm{v}), 0.1 \%$ $(\mathrm{v} / \mathrm{v})$, and $0.25 \%(\mathrm{v} / \mathrm{v}))$ of honey were added into the cells and incubated at $37{ }^{\circ} \mathrm{C}$ and $5 \% \mathrm{CO}_{2}$ for 24 hours. A $20 \mu \mathrm{l}$ of MTT reagent $(0.5 \mathrm{mg} / \mathrm{ml})$ was dispensed into each well and incubated for 2 hours. Subsequently, MTT reagent was aspirated and $200 \mu$ of dimethyl sulfoxide (DMSO) was added to solubilise the formazan. This technique was performed in a dark room. The absorbance was recorded using spectrophotometer under a wavelength of $450 \mathrm{~nm}$. Each experiment was 
replicated three times for each concentration and result obtained was compared with the control.

Data analysis. All proliferative activities of DPSCs were observed through the images taken by an inverted microscope (EVOS XL CORE, Thermo Fisher Scientific, USA) for 24 hours with the intervals at 0,6 th, 12 th, and 24 th hour. Images obtained were observed and compared with the control. Comparisons within the groups of data were analysed using ANOVA and the probability of $p<0.05$ was considered statistically significant.

\section{RESULTS}

Effect of Trigona spp. honey on culture media. Both Trigona spp. honey samples of 1 and 2 were tested for their stability with media containing DPSCs at the concentration of $0.01 \%$, $0.04 \%, 0.1 \%$ and $0.25 \% \mathrm{v} / \mathrm{v}$. Results showed that after 72 hours, all media did not change its appearance or colour as compared to the control medium (Figure 1).
Trigona spp honey 1

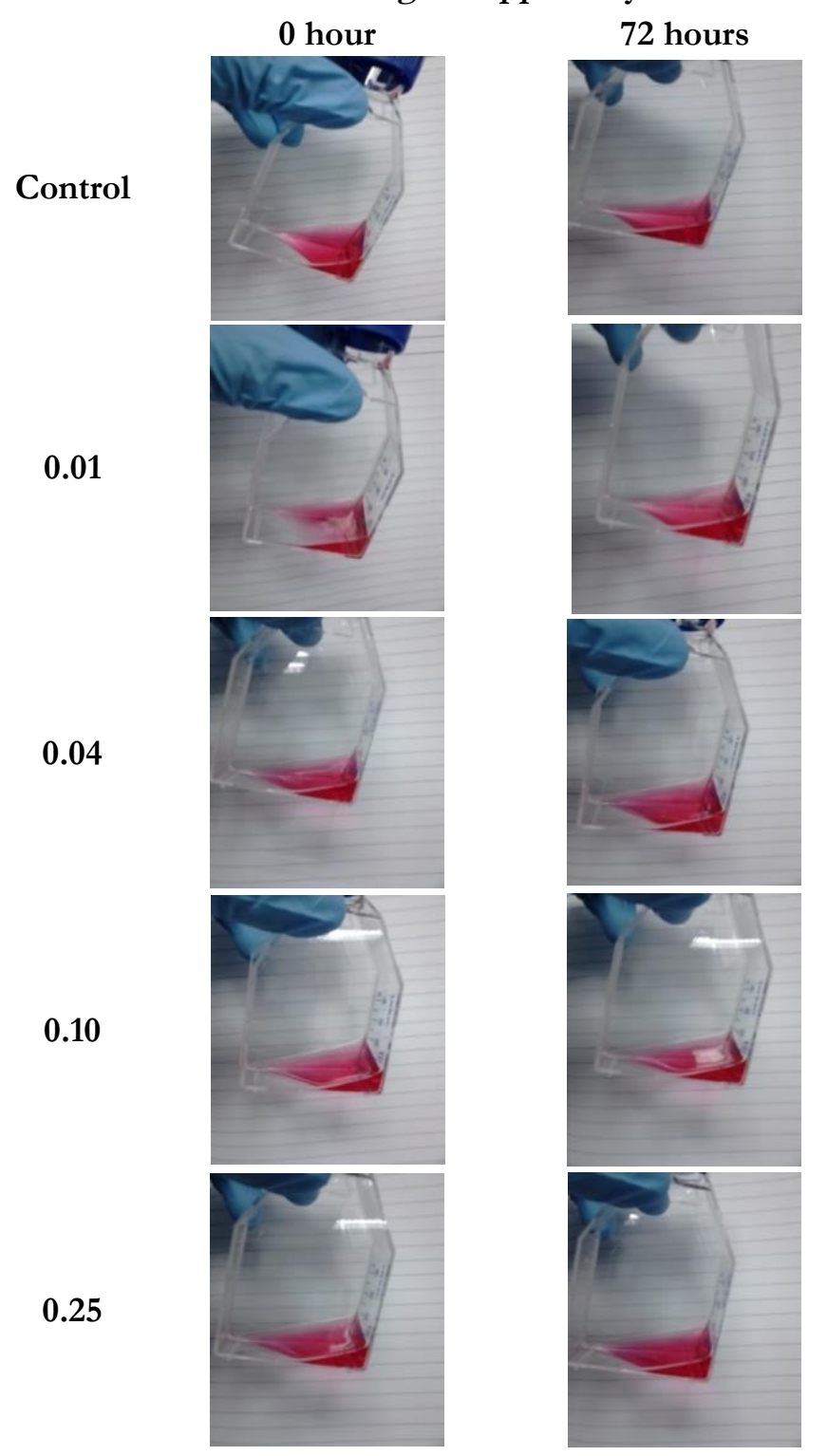

Trigona spp honey 2

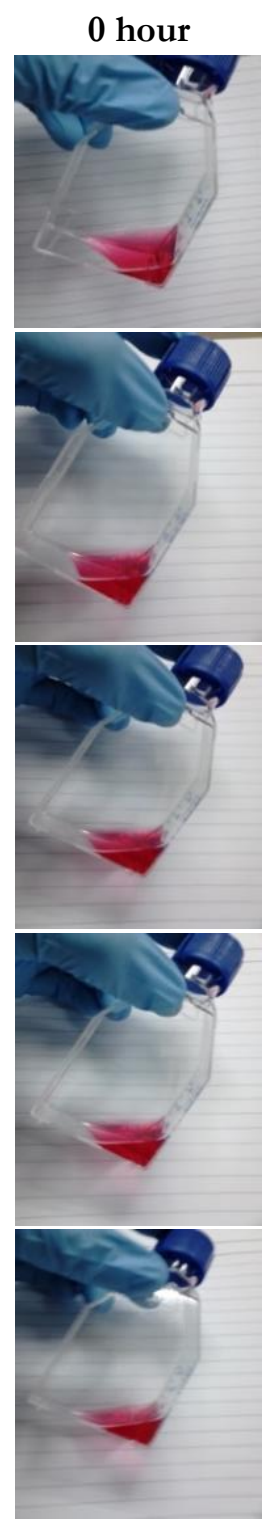

72 hours

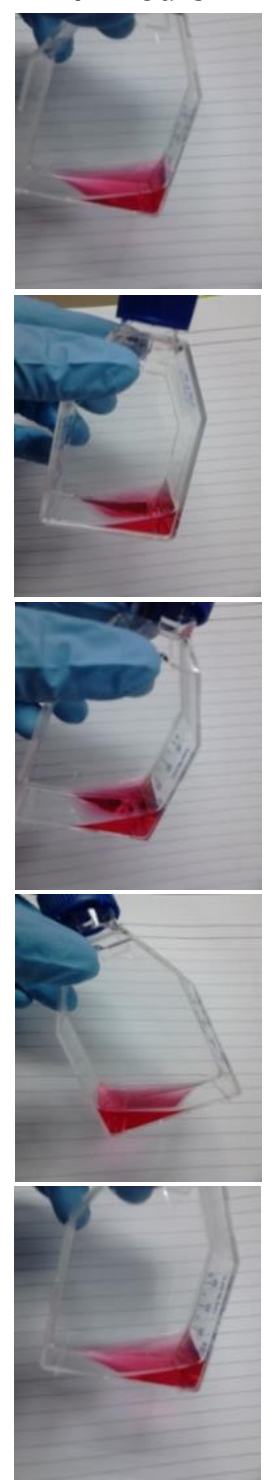

Figure 1. Comparison of media stability based on different concentrations of Trigona spp. honey 1 and 2.

Effect of Trigona spp. honey on DPSC proliferation. All the four concentrations showed relative proliferation activities when compared to the control. 
The obtained proliferative activities varied not only in concentrations and time, but also between the two different samples (Trigona spp. honey 1 and 2). The observations were made based on the result of the images captured which are more on the qualitative result and yet to be confirmed by MT'T assay for quantitative result.

Figure 2 shows the overall images of $15 \times 10^{3}$ DPSCs in 24 hours based on the different concentrations of Trigona spp. honey 1 (result for $5 \times 10^{3}$ and $10 \times 10^{3}$ are not shown). The bestseeded number of DPSCs cultured with Trigona spp. honey 1 was $15 \times 10^{3}$ and showed an increase in proliferation rate from $0.04 \%(\mathrm{v} / \mathrm{v})$ to $0.10 \%$ $(\mathrm{v} / \mathrm{v})$ concentration. However, the proliferation rate was slower at a higher concentration of $0.25 \%$ $(\mathrm{v} / \mathrm{v})$ (Figure 2). Meanwhile, in DPSCs treated with Trigona spp. honey 2 , higher proliferation rate was only observed at the concentration of $0.01 \%$ (v/v) (Figure 3). Therefore, higher proliferation rate was achieved 24 hours after being treated with both Trigona spp. 1 and 2. Thus, it can be suggested that both Trigona spp. honey 1 and 2 are able to induce a significant proliferation activity of DPSCs in their respective range of concentrations.

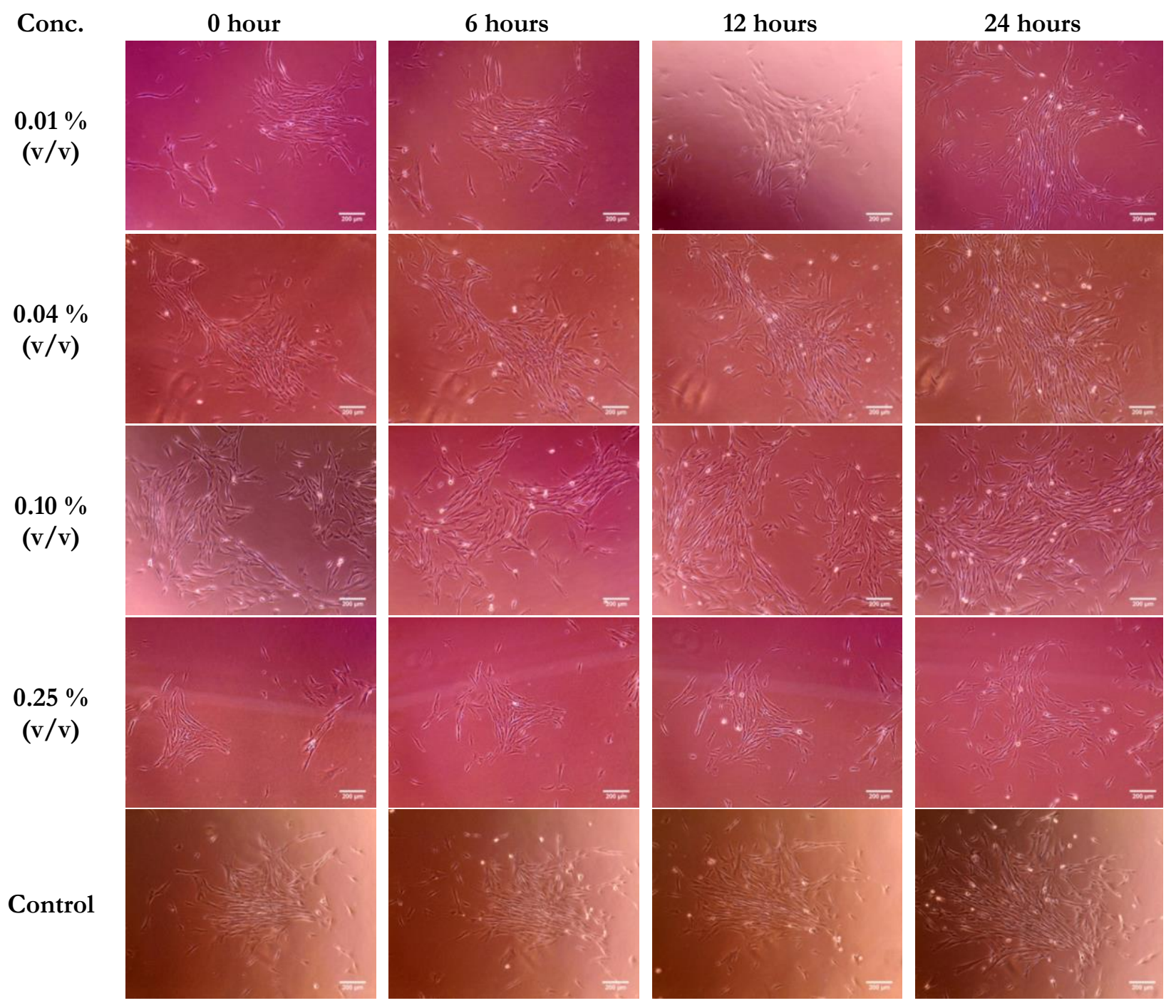

Figure 2. Overall images $15 \times 10^{3}$ DPSC in 24 hours based on different concentrations of Trigona spp. honey 1. Magnification X20. 


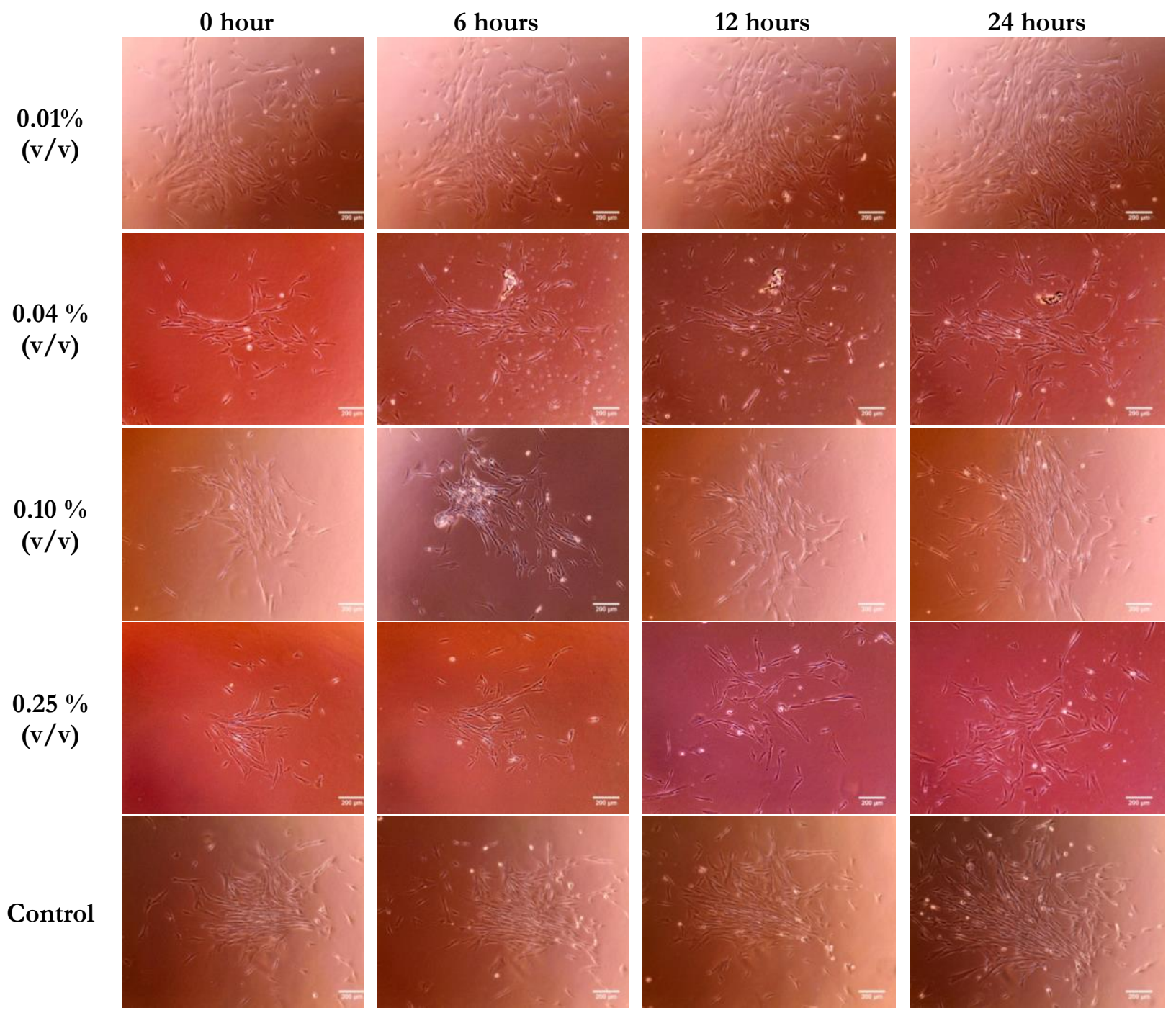

Figure 3. Overall images $15 \times 10^{3}$ DPSC in 24 hours based on different concentrations of Trigona spp. honey 2. Magnification X20.

Evaluation of honey on cell viability. To confirm the result obtained from the proliferation test, MTT assay was carried out to look at the optimum proliferation effects of both honeys. Only the concentrations that gave higher proliferative activity as compared to the control were chosen for cell viability test, which are Type 1 Honey $0.04 \%$ and $0.1 \%$, and Type 2 Honey $0.01 \%$ at $15 \times 10^{3}$ seeded cell number. Figure 4 demonstrated that the optimum proliferation effects of Trigona spp. honey 1 are within the concentration $0.04 \%(\mathrm{v} / \mathrm{v})$ and $0.10 \%(\mathrm{v} / \mathrm{v})$. Meanwhile, for Trigona spp. honey 2, the optimum value is at concentration $0.01 \%(\mathrm{v} / \mathrm{v})$ (Figure 5). In addition, both Trigona spp. honey 1 and 2 showed that the best-seeded number of DPSCs cultured was $15 \times 10^{3}$ cells/well.

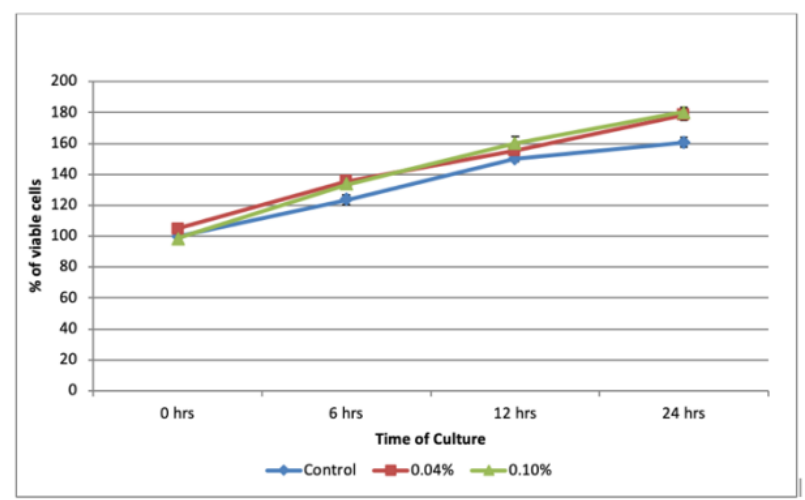

Figure 4. Effects of media added with Trigona spp. honey 1 on DPSCs at seeding density of 15,000 and treated at the concentrations of $0.04 \%$ and $0.10 \%$. Data are presented as \pm s.d. and represent of three experiments. Significance at pvalue is less than 0.05 . 


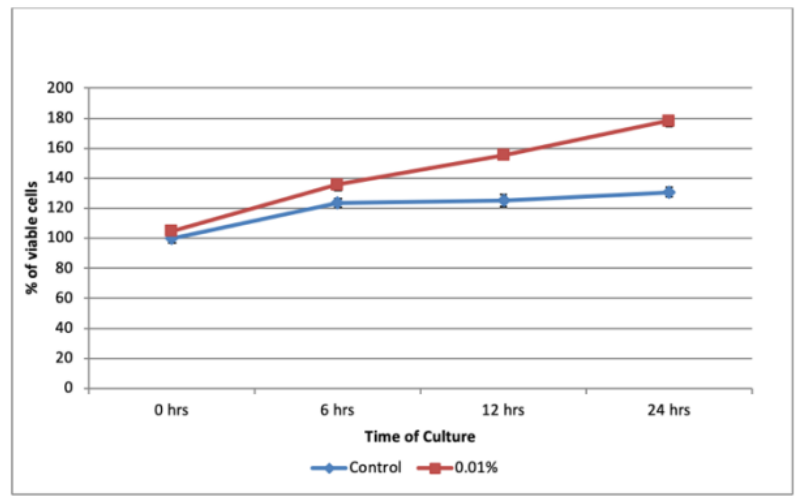

Figure 5. Effects of media added with Trigona spp. honey 2 on DPSCs at seeding density of 15,000 and treated at the concentration of $0.01 \%$. Data are presented as \pm s.d. and represent of three experiments. Significance at $\mathrm{p}$-value is less than 0.05 .

\section{DISCUSSION}

Honey is a very complex product because its chemical properties and composition depend not only on the nectar-providing plant species, but also on other factors such as the bee species, geographic area, season, mode of storage, harvest conditions, and even the interactions between the chemical compounds and enzymes in the honey. It is known that the accumulation of phytochemicals in honey depends on climatic conditions (sunlight, moisture), soil characteristics, and other factors. Therefore, it is reasonable to believe that the differences between honey from country to country appear due to the different compositions of pollen or nectar, which have the greatest influence on the chemical composition of honey. For instance, essential oil composition is very dependent on the geographical location even for the same plant species thus suggesting that even the same floral origin honey composition may be quite different (Kaškonienè \& Venskutonis, 2010).

Most of the available culture media include phenol red as a $\mathrm{pH}$ indicator, which allows constant monitoring of $\mathrm{pH}$. During the cell growth, the medium changes colour as $\mathrm{pH}$ is changed due to the metabolites released by the cells. At low pH levels (increased acidity), phenol red turns the medium to yellow, while at higher $\mathrm{pH}$ levels it turns the medium to purple. The medium is bright red for $\mathrm{pH} 7.4$, the optimum $\mathrm{pH}$ value for cell culture (Arora, 2013). From Figure 1 , images showed that there were no changes in the colour of DMEM media without DPSCs after being incubated for three days. This showed that the substances from both Trigona spp. honey 1 and 2 did not alter the stability of the media.

Media supplements are the growth media recommended for certain cell lines that require additional components which are not present in the basal media and serum. These components and supplements help to sustain cell proliferation and maintain normal cell metabolism (Arora, 2013). The additional substances from both Trigona spp. honey samples did not alter or change the standard culture media of DPSCs by providing a stable colour of $\mathrm{pH}$ 7.4.

The addition of Trigona spp. honey might affect the osmolality of the culture media as well as its stability. For most of the cell lines, optimal osmolality for culture media should be between $260 \mathrm{mOSM} / \mathrm{kg}$ and $320 \mathrm{mOSM} / \mathrm{kg}$ (Arora, 2013). Thus, the change of the culture media osmolality will affect the DPSCs proliferative activities. This factor may be the reason why Trigona spp. honey 1 showed proliferative activity at $0.04 \%$ and $0.10 \%$ concentration, while Trigona spp. honey 2 showed only active proliferative activity at $0.01 \%$ concentration. Both of the Trigona spp. honey samples may have different osmolality due to the different chemical compositions and concentrations since the addition of supplements from honey can change the osmolality of the complete growth media that can negatively affect the growth of cells. It is always best to recheck the osmolality after supplements are added because it is essential in ensuring that the cells can keep surviving and proliferating. High osmolality could affect the water from the cells to rush out, resulting in shrinkage. Therefore, the addition of the supplements in the honey might alter the osmolality that can affect the proliferation of the cells.

MTT assay was done to determine the best seeding number for DPSCs to proliferate at optimum range. Three different ranges of cell seeding number were tested in this study; namely $5 \times 10^{3}, 10 \times 10^{3}$, and $15 \times 10^{3}$ cells/well. The best seeding number of DPSCs was chosen by comparing the overall triplicate of the DPSCs through proliferation test and viability test using the MTT assay. Cell density or cell seeding 
number is known to control the rate of proliferation of cells in culture. The transport of small nutrients also depends on the cell density. It decreases when cell density increases and vice versa. Increases in the uptake of low molecularweight nutrients are among the early events associated with the initiation of cell growth (Piedimonte, Borghetti \& Guidotti, 1982).

From previous studies, Xia et al. (2011) stated that a wide range of endothelial cell seeding densities from $4 \times 10^{3}$ to $2 \times 10^{5}$ cells $/ \mathrm{cm}^{2}$ have been used for in vitro studies on cell-biomaterial interaction. Stimuli from the neighbouring cells via the interaction of cell surface receptors and secreted growth factors or cytokines are strongly dependent on the cell density. When the cell density is low, direct cell-cell contacts are limited and cell-biomaterial interaction is expected to be pre-dominantly influenced by cell-substrate contact. Compared to the low seeding density, cell-cell interaction at high seeding density is more extensive, which could contribute to cell attachment signalling activation through crosstalk between cell-substrate and cell-cell adhesion (Xia et al., 2011). Thus, this previous finding is similar to the present study in which the number of seeding cells was found to influence the cells' proliferation activity.

Stem cells exhibit variable differentiation and proliferation characteristics of the same cell line if it is grown in different types of serum and can also present different phenotypes if cultivated in different conditions. Nevertheless, the cellular requirement for a specific micronutrient is directly correlated with the cell type, the rate of cell growth, and the stage of cell differentiation (Arigony et al., 2013).

Based on Figures 2 and 3, at concentrations between $0.04 \%(\mathrm{v} / \mathrm{v})$ and $0.10 \%(\mathrm{v} / \mathrm{v})$ for honey 1 , the best proliferation time for DPSCs was 24 hours. Similarly, the best time for proliferation is 24 hours for Trigona spp. honey 2 at the concentration of $0.01 \%(\mathrm{v} / \mathrm{v})$. Xia et al. (2011) stated that as cell density increases, cell-cell interaction also increases and it is expected to profoundly influence cellular responses to biomaterials.

The composition of honey is rather varied and depends primarily on its floral source, however, certain external factors, such as seasonal environmental factors and processing methods also play a role. The varying proliferative effect of honey may be due to the different substances and depends on the botanical origin of honey. For example, different antimicrobial chemicals were found on different bee honey; methylglyoxal was discovered to contribute to the activity of New Zealand's Manuka honey, bee defensin-1 was detected in a Dutch honey, and melanoidins were identified in Canadian honeys (Moussa et al., 2012).

Phenolic compounds may be one of the factors that increase the proliferative activity of DPSCs as compared to the standard culture media. The compounds, such as flavonoids, caffeic acid, di-hydroxy benzoic acid, cinnamic acid, and ferulic acid are found in different types of honey at various concentrations depending on the location and botanical sources (Yao et al., 2003; Jaganathan \& Mandal, 2009; Tsiapara et al., 2009). As for the stingless bee honey, specifically Trigona spp. honey, it is found that the honey contain free phenolic acids, including phenylpropanoic acid, benzoic acid, 4hidroxybenzoic acid, 4-hydroxyphenylacetic acid, vanillic acid, protocatechuic acid, and p-coumaric acid (Roowi et al., 2012). In the present study, there are possibilities that one or more of the phenolic acids or compounds mentioned above might be the component that contributed to the proliferative effect on DPSCs. Thus, further study to identify the compounds and their effects is needed.

Other factors that influence the proliferation rate of DPSCs also need to be taken into consideration. An extensive review of the antimicrobial activity of honey showed it to be derived from high sugar content, low water content, acidity, the generation of hydrogen peroxide on dilution, and phytochemical components (Moussa et al., 2012).

In this study, the MTT assay was used to observe the optimum concentration of both honey toward the cell proliferation effect of DPSCs. Based on the data that we had, at $15 \times 10^{3}$ seeded cell number, the optimum concentration of Trigona spp. honey 1 is between $0.04 \%(\mathrm{v} / \mathrm{v})$ and $0.10 \%(\mathrm{v} / \mathrm{v})$, as compared to the control. In a comparison with the control, the optimum concentration of honey 2 is $0.01 \%(\mathrm{v} / \mathrm{v})$. Therefore, when the concentration is less than the optimum value, the honey might show slow 
proliferation effects. However, if the concentration of honey is greater than the optimum value, it might cause a reduction in the cell proliferation activity.

\section{CONCLUSION}

This study demonstrated that Trigona spp. honey 1 and 2 have a promising proliferative effect on DPSCs. This honey was found to not have any effect towards the media stability within three days of incubation. It also increased the proliferation rate of DPSCs as early as 24 hours with $0.04 \%$ and $0.10 \%$ concentrations of Trigona spp. honey 1 and only $0.01 \%$ concentration of Trigona spp. honey 2 as compared to the control.

\section{ACKNOWLEDGEMENTS}

This study was financially supported by the International Islamic University Malaysia with grant number FRGS15-253-0494.

\section{REFERENCES}

Aljadi, A., \& Kamaruddin, M. 2004. Evaluation of the phenolic contents and antioxidant capacities of two Malaysian floral honeys. Food Chemistry 85: 513-518.

American Cancer Society. 2013. Breast Cancer Overview. Retrieved May 2014, from American Cancer Society Website: http://www.cancer.org.

American Cancer Society. 2014. Cancer Facts \& Figures 2014. Atlanta: American Cancer Society.

Andualem, B. 2013. Combined antibacterial activity of stingless bee (Apis mellipodae) honey and garlic (Allium sativum) extracts against standard and clinical pathogenic bacteria. Asian Pacific Journal of Tropical Biomedicine 3(9): 725-731.

Bogdanov, S., Jurendic, T., Sieber, R., \& Gallman, P. 2008. Honey for nutrition and health: a review. American Journal of the College of Nutrition 27: 677-689.

Boorn, K., Khor, Y. Y., Sweetman, E., Tan, F., Heard, T., \& Hammer, K. (2010). Antimicrobial activity of honey from the stingless bee Trigona carbonaria determined by agar diffusion, agar dilution, broth microdilution and time-kill methodology. Journal of Applied Microbiology 108: 1534-1543.

Boyle, P., \& Levin, B. (2008). World Cancer Report. Lyon: Intenational Agency for Research on Cancer. Cancer Research UK. 2013. What is Cancer? Retrieved May 2014, from Cancer Research UK Website: http://www.cancerresearchuk.org/cancer-help/aboutcancer/what-is-cancer.
Cantwell, A. 2010. Immortal HeLa Cells and the continuing contamination of cancer and vaccine research. Retrieved May 2014, from Rense.com: http://rense.com/general89/ immot.htm.

Chaudhry, M., Chodosh, L., McKenna, W., \& Muschel, R. (2002). Gene expression profiling of HeLa in G1 or G2 phases. Oncogene 21: 1934-1942.

Choudari, M. K., Haghniaz, R., Rajwadee, J. M., \& Paknikar, K. M. 2013. Anticancer activity of Indian stingless bee propolis: an in vitro study. Evidence-Based Complimentary and Alternative Medicine 2013.

Cooper, R., Molan , P., Krishnamoorthy, L., \& Harding, K. 2001. Manuka honey used to heal a recalcitrant surgical wound. European Journal of Clinical Microbiology and Infectious Diseases 20(10): 758-759.

Fauzi, A. N., Norazmi, M. N., \& Nik Soriani, Y. 201). Tualang honey induces apoptosis and disrupts the mitochondrial membrane potential of human breast and cervical cancer cell lines. Food and Chemical Toxicology 49: 871-878.

Fukuda, M., Kobayashi, K., Hirono, Y., Miyagawa, M., Ishida, T., Ejiogu, E. C., et al. 2008. Jungle honey enhances immune function and antitumour activity. Evidence-Based Complementary and Alternative Medicine 2011.

Garcia, M., Jemal, A., \& Ward, E. 2007. Global Cancer Facts \& Figures 2007. Atlanta: American Cancer Society.

Ghashm, A., Othman, N., Khattak, M., Ismail, N., \& Saini, R. 2010. Antiproliferative effect of Tualang honey on oral squamous cell sarcoma and osteosarcoma cell lines. BMC Complimentary and Alternative Medicine 10: 1-8.

Gomez-Caravaca, A., Gomez-Romero, M., Arraez-Roman, D., Segura-Carretero, A., \& Fernandez- Gutierrez, A. 2006. Advance in analysis of phenolic compounds in products derived from bees. Journal of Pharmacentical and Biomedical Analysis 41(4): 1220-1234.

Helena, A., Alencar, G. De, \& Kitten, G. T. 2011. Mesenchymal stem cells in the dental tissues: Perspectives for tissue regeneration. Brazilian Dental Journal 22: 91-98.

Holiday, D. L., \& Speirs, V. 2011. Choosing the right cell line for breast cancer research. Breast Cancer Research 13: 215.

IARC. 2014. Estimated Cancer Incidence, Mortality and Prevalence Worldwide in 2012. Lyon: World Health Organization (WHO).

Khalil, M. I., Sulaiman, S. A., Alam, N., Ramli, N. O., Mohamed, M., Bai'e, S., \& Hua, G. S. 2012. Content and antioxidant properties of processed Tualang honey (Agromas) collected from different regions in Malaysia. International Journal of Pharmacy and Pharmaceutical Sciences 4: 214-219.

Jaganathan, S., \& Mandal, M. 2009. Antiproliferative effects of honey and its polyphenols: a review. BioMed Research International 2009.

Jaganathan, S., \& Mandal, M. 2009. Honey constituents and their apoptotic effect in colon cancer. Journal of ApiProduct and ApiMedical Science 7(25): 29-36.

Jemal, A., Bray, F., Center, M. M., Ferlay, J., Ward, E., \& Forman, D. 2011. Global Cancer Statistics. CA: A Cancer Journal for Clinicians 61: 69-90.

Khalil, M. I., Sulaiman, S. A., \& Boukraa, L. 2010. Antioxidant properties of honey and its role in preventing health disorder. The Open Nutracenticals Journal 3: 6-16.

Klakasikorn, A., Wongsiri, S., Deowanish, S., \& Duangphakdee, O. 2005. New record of stingless bees (Meliponini: Trigona) in Thailand. The Natural History Journal of Chulalongkorn University 5(1): 1-7.

Kustiawan, P. M., Puthong, S., Arung, E. T., \& Chanchao, C. 2014. In vitro cytotoxicity of Indonesian stingless bee products against human cancer cell lines. Asian Pacific Journal of Tropical Biomedicine 4(7): 549-556. 
Levenson, A. S., \& Jordan, V. C. 1997. MCF-7: The first hormoneresponsive breast cancer cell line. Cancer Research 57: 3071 3078.

Ma, J., Dong, C., \& Ji, C. 2010. MicroRNA and drug resistance. Cancer Gene Therapy 17: 523-531.

Molan, P. C. 2006. The evidence supporting the use of honey as a wound dressing. International Journal of Experimental of Lower Extremity Wounds 5(1): 122.

Moniruzzaman, M. C. 2014. Determination of minerals, trace elements, and pesticide levels in honey sample originating from different regions in Malaysia compared to Manuka honey. Biomed Research International.

Mosmann, T. 1998. Rapid colorimetric assay for cellular growth and survival: application to proliferation and cytotoxicity assay. Journal of Immunological Methods 65: 55-63.

Moutsatsou, P. 2007. The spectrum of phytoestrogens in nature: Our knowledge is expanding. Hormones 6: 173-193.

National Cancer Institute. 2014. What is Cancer? Retrieved May 2014, from National Cancer Institute at the National Institutes of Health. Website:http://www.cancer.gov/ cancertopics/cancerlibrary/what-is-cancer.

Yaacob, N. S., Nengsih, A., \& Norazmi, M. 2013. Tualang honey promotes apoptotic cell death induced by tamoxifen in breast cancer cell lines. Evidence-Based Complementary and Alternative Medicine 2013.

Nikolić, N., Krstić, A., Trivanović, D., Mojsilović, S., Kocić, J., Santibanez, J. F., et al. 2011. Mesenchymal stem cell properties of dental pulp cells from deciduous teeth. Arcbives of Biological Sciences 63(4): 933-942.

Othman, N. H. 2012. Honey and cancer: Sustainable inverse relationship paricularly for developing nations - a review. Evidence-based Complimentary and Alternative Medicine 2012.

Lazim, N. M., Abdullah, B., \& Salim, R. 2013. The effect of Tualang honey in enhancing post tonsillectomy healing process. An open labelled prospective clinical trial. International Journal of Pediatric Otorbinolaryngology 77(4): 457461.

Ooi, K. L., Muhammad, T. S. T. \& Sulaiman, S. F. 2013. Physalin F from Physalis minima L. triggers apoptosis-based cytotoxic mechanism in T-47D cells through the activation caspase3- and c-myc-dependent pathways. Journal of Ethnopharmacology 150(1): 382-388.

Oršolić, N. 2009. Bee honey and cancer. Journal of ApiProducet and ApiMedical Science 1(4): 93-103.

Pyrzynska, K., \& Biesaga, M. (2009). Analysis of phenolic acids and flavonoids in honey. TrAC Trends in Analytical Chemistry 81(2): 893-902.

Roowi, S., Aisyah, M., Hamdan, S., Mohd. Fahimee, J., Mohd. Nazrul Hisham, D., \& Rosnah, O. 2012. Asid fenolik bebas dalam madu kelulut. Buletin Teknologi MARDI, Bil. 1.

Roubik, D. W. 2006. Stingless bee nesting biology. Apidologie 37: 124-143.

Sarkar, F., Banerjee, S., \& Li, Y. 2007. Pancratic cancer: Pathogenesis, prevention and treatment. Toxicology and Applied Pharmacology 224: 326-336.

Shahjahan , M. \& Halim, N. A. B. A. 2007. Antimicrobial properties of "Kelulut" (Trigona spp) honey. Malaysian Journal of Medical Sciences 14(1): 107-108.

Sherlock, O., Dolan, A., Athman, R., Power, A., Gethin, G., Cowman, S., et al. 2010. Comparison of antimicrobial activity of Ulmo honey from Chile and Manuka honey against methicilin-resistant Staphylococcus aureus, Eschericbia coli and Pseudomonas aeruginosa. BMC Complimentary and Alternative Medicine 10: 47.

Su, D. M., Zhang, Q., Wang, X., He, P., Zhu, Y. J., Zhao, J., et al. 2009. Two types of human malignant melanoma cell lines revealed by expression patterns of mitochondrial and survival-apoptosis genes: implications for malignant melanoma therapy. Molecular Cancer Therapentics 8(5): 12921304.

Tan, H. T., Rahman, R. A., Gan, S. H., Halim, A. S., Asma'Hassan, S., Sulaiman, S. A. \& Kirnpal-Kaur, B. S. 2009. The bacterial properties of Malaysian Tualang honey against wound and enteric microorganisms in comparison to Manuka honey. BMC Complimentary and Altenatives Medicine 9: 1-8.

Tsiapara, A. V., Jaakkola, M., Chinou, I., Graikou, K., Tolonen, T., Virtanen, V., et al. 2009. Bioactivity of Greek honey extracts on breast cancer (MCF-7), prostate cancer (PC-3) and endometrial cancer (Ishikawa) cell: Profile analysis of extracts. Food Chemistry 116: 702-708.

Valko, M., Leibfritz, D., Moncol, J., Cronin, M., Mazur, M., \& Telser, J. 2007. Free radicals and antioxidants in normal physiological functions and human disease. The International Journal of Biochemistry \& Cell Biology 39(1): 44-84.

Yao, L., Datta, N., Tomás-Barberán, F., Ferreres, F., Martos, I., \& Singanusong, R. 2003. Flavonoids, phenolic acids and abscisic acid in Australian and New Zealand Leptospermum honeys. Food Chemistry 81(2): 159-168. 